Outeur: $\quad$ Maritz Spaarwater

Titel: $\quad$ Die spook wat boomgeklim en die lig gevind het: 'n Memoire met herinneringe uit die binnekring van Suid-Afrika se vreedsame revolusie na demokrasie

Uitgewer: Hermanus: Erfenis Publikasies, 2015

Bladsye: $\quad 358 \mathrm{pp}$

ISBN: $\quad 9781928283133$

Prys: \$12,53-Kindle Uitgawe @ amazon.com

Daar is min lande in die wêreld wat die diepliggende en ingrypende politieke, sosiomaatskaplike en kulturele verandering deurloop het, waaraan Suid-Afrika onderwerp is in die laaste drie dekades van die 20ste Eeu. Op 'n manier is Suid-Afrika, selfs na meer as 20 jaar van demokratiese regering, nog nie gereed om sy eie verlede in konteks, diepte en omvang te konfronteer nie. Die Suid-Afrikaanse verlede word daarom dikwels deur sy verskillende gemeenskappe met uiteenlopende perspektiewe bejeën. Daar is veral 'n geneigdheid om ongenuanseerd en afskrywend om te gaan met Suid-Afrika se apartheidsverlede en burokrasie, asof daar nie ook dikwels goed uit die kwaad na vore gekom het nie en asof daar niks te leer is uit Suid-Afrika se apartheidsverlede en burokratiese bestuur van die land nie. Gevolglik is Suid-Afrika sedert 1994 dikwels vanuit hierdie realiteit gekonfronteer met verandering ter wille van verandering. In die proses is werkende stelsels soms vernietig in die naam van apartheidskontaminasie.

Die outeur van Die Spook wat Boomgeklim en die Lig gevind het is terdeë bewus van die verantwoordelikheid wat daar rus op diegene wat deel was van die prosesse van demokratisering om hul deel van die geskiedenis op te teken. Hy argumenteer dat dit sy verantwoordelikheid is om die geskiedenis "... eerlik en onbevange [te] beskryf, interpreteer en vir bewaring te boekstaaf" (p. 165) ten einde te voorkom dat "... ideologies- en naywer-gedrewendes" die geleentheid aangryp om hul voorkeursiening te verewig - sieninge wat "... ons al uit ervaring weet gretig aangegryp sal word, ook veral in huidige [2015] regeringskringe en die akademiese wêreld" (p. 165).

Spaarwater beskryf die boek as "... 'n onvolledige memoire eerder as 'n outobiografie" omdat hy "... geen skouspelagtige mislukkings of wêreldskuddende suksesse behaal [het] waarvan vertel behoort te word nie" (p. 16). Die boek is daarom 'n beperkte lewensbeskrywing wat verband hou met die verloop van die onlangse geskiedenis en die invloede wat hom as persoon gevorm het (p. 15). Hy verkies om die boek as 'n impressionistiese vertelling voor te hou omdat hy nie wil aanspraak maak op “... wetenskaplike historisiteit” (p. 16) nie. Die motivering vir die skryf van die boek spruit voort, eerstens, uit die noodsaak om op sy lewe te reflekteer. "Meer volledige begrip", skryf die outeur in refleksie op sy eie lewe, "kristalliseer dikwels eers uit wanneer jy later terugskouend daarna kyk, en soms verbaas is oor wat jy van jouself ontdek" (p. 13). Die outeur hoop, tweedens, dat die boek perspektief sal werp op bepaalde historiese gebeure en invloede wat die oorsake en verloop van die onderhandelde skikking in Suid-Afrika onderlê het. Derdens, wys die skrywer daarop dat hy 'n verduideliking aan sy nageslag verskuldig is oor "... wat en hoe ek is en hoekom ek, weens die vereistes van daardie beroepe so dikwels afwesig was toe hulle en hulle ma my nodig gehad het" (p. 15). Laastens, werp die skrywer lig op die “... eerbare mans en vrouens [wat hul] bes gedoen het om legitieme doelwitte met regmatige middele na te jaag om vir hulle 'n voorspoedige en gelukkige toekoms te probeer verseker" (p. 15).

Die Spook wat Boomgeklim en die Lig gevind het plaas die fokus op en handel nie net oor die apartheidsera nie. Die fokus is spesifiek op die rol van die, soms kontroversiële, 
inligtingsburokrasie vanuit daardie era. Die outeur se betrokkenheid en loopbaan wat by Militêre Inligtingsdiens begin het, oorgespoel het na die Nasionale Intelligensiediens en uiteindelik by die Staatkundige Ontwikkelingsdiens geeïndig het, plaas hom in 'n uitstekende posisie om die, volgens hom, vreedsame revolusie wat Suid-Afrika se eerste demokratiese verkiesing voorafgegaan het, te belig vanuit 'n binneperspektief. Die boek verskaf sonder twyfel 'n genuanseerde, in-diepte, agter-die-skerms regeringsperspektief van Suid-Afrika se oorgang na demokrasie en die rol wat die inligtingsgemeenskap in dié verband gespeel het.

Die drie instellings waarvan Spaarwater deel was in sy loopbaan, die Suid-Afrikaanse Weermag (SAW), die Nasionale Intelligensiediens (NI) en die Staatkundige Ontwikkelingsdiens, het sonder twyfel oor tyd kritieke rolle gespeel in die ontvouing van die onderhandelde skikking in Suid-Afrika - beide in die bestuur van die proses en die skepping van die veligheidsklimaat wat nodig was vir die proses om sy loop te neem. Die outeur belig die rolle wat hierdie instellings gespeel het vanuit 'n persoonlike en institusionele perspektief. Sy fyn waarneming en die gedetaileerde genuanseerde beskrywings van gebeure waarvan hy deel was, sonder om homself sentraal te plaas, maak die boek 'n absolute plesier om te lees. Sy beskrywing van sentrale figure in hierdie spesifieke burokrasieë en sleutel-politieke en burokratiese figure uit die apartheidsera en oorgangstydperk met wie hy in aanraking was dikwels in interessante omstandighede - dien spesifiek vermeld te word.

Daar is min professies wat so interessant is en wat die mate van persoonlike inisiatief en verantwoordelikheid vereis, soos die inligtingsdienste. Spaarwater se innerlike dryfkrag kom op allerlei wyses in die boek na vore. Om as jong Afrikaanssprekende 'n honneursgraad in internasionale betrekkinge by die Universiteit van die Witwatersrand aan te pak en later suksesvol en op eie inisiatief ' $n$ LLM in Internasionale Reg van Cambridge Universiteit te voltooi, is maar net een voorbeeld in dié verband. Die boek is gevolglik geskryf deur 'n persoon wat akademies goed onderlê is, maar wat ook oor die lewenswyshede en insigte van 'n deurwinterde inligtingsoperateur beskik. Die gebalanseerde omgang met die geskiedenis en sy eie rol daarin, kan waarskynlik aan die outeur se regsagtergrond toegeskryf word.

Die boek is die skrywer se verwerkte vertaling in Afrikaans van sy boek A Spook's Progress: From Making War to Making Peace. Synde eers die Engelse weergawe van die boek te gelees het, het die outeur se gemaklike, dog fyn, raak en genuanseerde gebruik van Engels my opgeval. Dit is inderdaad ook die geval met die Afrikaanse uitgawe van die boek. Die vertaling is presies, akkuraat en fyn. Die skryfstyl is fassinerend, vars, eerlik en opreg. Spaarwater dra nie swaar aan die verlede nie en die boek is nie vanuit en met 'n kniebuigende of verskonende ingesteldheid geskryf soos dikwels die geval is met boeke oor daardie era nie. Dit sal nie verkeerd wees om dit as 'n lekkerleesboek te beskryf nie.

Aangesien inligtinginstellings bestaan en funksioneer in 'n wolk van geheimhouding, lewer Spaarwater se boek 'n geweldige bydrae om die sluier te lig oor en die algemene publiek insae te gee in die werksaamhede van hierdie instellings tydens die apartheidsera. Een van die sake wat ooglopend aan die orde van die dag kom, is die realiteit dat hierdie instellings nie net afgestuur is op die insameling van inligting nie; dat James Bond-tipe koverte spioenasiewerk maar ' $n$ baie klein deel uitmaak van wat inligtingsinstellings doen. In baie gevalle bied die vertroulikheid van die wêreld waarin hierdie instellings bestaan, uitstekende geleenthede aan bewindhebbers om die belange van 'n staat in die geheel te bevorder deur agter-die-skerms onderhandelinge en diplomasie.

Uiteraard is die verhouding tussen die inligtinggemeenskap en die politieke elite in die meeste samelewings 'n hoogs kontroversiële aangeleentheid wat baie debat en uiteenlopende sieninge na vore bring. In die meeste gevalle word hierdie verhouding belyn deur die politieke 
kwesbaarheid van die elite en die professionaliteit van die inligtingsgemeenskap. Die een faktor wat telkens in Spaarwater se boek na vore kom, is die uiterste toewyding, bekwaamheid en professionaliteit van Suid-Afrika se militêre en inligtingsburokrate tydens die era wat aan die orde is. Dit was ' $n$ bepalende faktor in hoe die politieke toneel in Suid-Afrika ontvou het en 'n belangrike les wat nie sonder oorweging in en vir die huidige era verlore mag gaan nie.

Laastens, en in die konteks van die geweldige debatte wat tans aan die orde van die dag is oor die voortgesette gebruik van Afrikaans op tersiêre vlak en die veel-herhaalde bewerings en impliserings - ook deur Afrikaners en Afrikaanssprekendes - dat akademiese uitnemendheid nie in Afrikaans bereik kan word nie (kyk bv. p. 328 e.v. van die boek), 'n opmerking. Die skrywer se BJuris in Afrikaans van Tukkies het aan hom die platform verskaf vir sy voortgesette studies by die Universiteite van Witwatersrand en Cambridge. Dit is maar net een van die sprekende voorbeelde van moedertaalonderrig wat bemagtig en weerlê die oordrewe en misplaaste fokus op Engels as onderrigtaal wat klaarblyklik afgestuur is op toegang tot die internasionale omgewing.

\section{Abel Esterhuyse}

E-pos: Abel@ma2.sun.ac.za 